\title{
Combination Effect of Golden Snail Powder and Fermented Coconut Cake on Quality of Duck Eggs
}

\author{
Nurmauliah Syaharuddin, , Rasdiyanah, Dwi Kesuma Sari, Wa Ode Santa Monica, \\ Abdul Wahid Jamaluddin*
}

\author{
Study Program of Veterinary Medicine, Faculty of Medicine, Hasanuddin University, Jl. Perintis \\ Kemerdekaan Km. 10, Makassar, South Sulawesi 90245
}

*Corresponding author: Abdul Wahid Jamaluddin (abdulwahidjamaluddin@unhas.ac.id)

\begin{abstract}
This study aims to determinate the effect of combination golden snail powder and fermented coconut cake on quality of duck eggs. We were using experimental feeds combination form golden snail powder and fermented coconut cake as raw material for livestock rearing for duck. This research was conducted in July - September 2018 in Mangkoso Village, Barru Regency and continued with sample testing at the Laboratory Animal Husbandry Faculty of Livestock Product Technology University of Hasanuddin. This study used 16 female duck who are 20 weeks old with four types of treatments consists of four replications of each treatment. The egg quality was carried out using a sample of 16 eggs from Ducks which was maintained and treated with different rations. The data obtained were analyzed using variance analysis with a Completely Randomized test for significant different results. The results of the combination of golden snail powder and fermented coconut cake on egg color, egg white index, egg yolk index, haugh unit (HU) value of egg units. All treatments (P1, P2, P3) gave effect to three parameters, namely eggshell quality, egg yolk index and egg yolk color, while the other three parameters namely egg weight, egg white index and Haugh Unit (HU) value did not differ significantly from negative controls. The best treatment was shown by treatment $P 3$ which gave an effect on the heavier egg weight than other treatments, eggshell quality grade A, Egg White Index and Egg Yolk Index showed good quality and bright golden egg yolks.
\end{abstract}

Key words: Ducks eggs, rations, golden snail powder, fermented coconut cake, quality of eggs

Copyright $\odot 2019$ JRVI. All rights reserved.

\section{Introduction}

The ducks population in Indonesia reaches 34,093,31, and the meat of ducks production was $25,300,000 \mathrm{~kg}$ and eggs 202,500,000 kg (Central Statistics Agency, 2007). Compared to freerange chicken, ducks have higher egg productivity and more profitable if kept Most people consider this mollusk as a rice pest. Potential damage to plants by golden snails ranges from 10 to $40 \%$. At present the snail golden is still a threat to farmers, especially in areas such as Java, Sumatra, Kalimantan, NTB, and Bali (Budiyono, 2006). Some previous studies revealed that the protein nutritional value of golden snail meat is very high to be used as feed for laying ducks if processed properly and correctly. One of the nutritionally valuable substances in eggs and shells of golden snails is carotenoid which can be used to increase the index of duck egg yolk (Mualim et al., 2014). 
Coconut cake is a waste of palm oil processing and based on its chemical composition, cake coconut is a protein source for livestock. Coconut cake can be used no more than $20 \%$ for puoultry, pigs $40-50 \%$ and ruminants $30 \%$ (Ridla, 2003). Previous research stated that coconut cake which has undergone a fermentation process has an effect on egg quality. (Sinurat et al., 1998).

\section{Materials and Methods}

The study was conducted experimentally using a completely randomized design (CRD). The sample were divided into four groups where each group consists of 4 laying ducks. The ducks used in this study were laying ducks of equal age (4-5 months) or in productive times. Feed ingredients which is used for the preparation of the feed consists from bran, yellow corn, golden snail powder (SKM), fermented coconut cake (BKT), and EM-4 for coconut cake fermentation. The arrangement of treatments can be described as follows (Prasetyo et al., 2010 ):

$$
\begin{array}{ll}
\text { P0 } & =\text { Basal ration (Rice Bran }+ \text { Yellow Corn }+ \text { Chalk Flour }+ \text { Salt }+ \text { Premix) (Control) } \\
\text { P1 } & =\text { Basal ration }+6 \% \text { SKM }+10 \% \text { BKT } \\
\text { P2 } & =\text { Basal ration }+8 \% \text { SKM }+15 \% \text { BKT } \\
\text { P3 } & =\text { Basal ration }+10 \% \text { SKM }+20 \% \text { BKT }
\end{array}
$$

The research procedure was initiated by making Golden Snail Powder (SKM) according to Puspitasari (2010) and the manufacture of Fermented Coconut Cake (BKT) according to the instructions of Rotib (2000). Ducks are kept for \pm 2 months until they reach a productive period and are adapted together with their respective groups. During the adaptation period, ducks are given 2 times a day in the form of bran and corn and ad libitum drinking water. After reaching the productive period, ducks are kept in accordance with their respective treatment groups. All groups were fed twice a day. The collection of eggs is done every day before feeding in the morning. The eggs collected in the egg rack will be grouped according to the treatment duck groups.

The egg samples tested for the Egg White Index (IPT), Egg Yolk Index (IKT), Haugh Unit (HU) by using the calipers as well as testing the yolk density with the help of the color meter/color analyzer.

\section{Egg White Index / Albumin}

According to Indrawan et al (2012 ): broken eggs, placed on flat glass, and measured albumin height, albumin diameter 1 (long diameter), and albumin diameter 2 (short diameter) using the calipers, then calculated the albumin index using the following formula :

$$
\begin{aligned}
& \text { Albumin index }=\frac{a}{\frac{(b 1+b 2)}{2}} \\
& \text { Information : } \\
& \text { a : high albumin } \\
& \text { b1: albumin diameter } 1 \\
& \text { b2: albumin diameter } 2
\end{aligned}
$$

\section{Egg Yolk Index}

According to Indrawan et al (2012 ): broken eggs, placed on flat glass, then measured the height of the yolk and the diameter of the yolk with the calipers, then calculated the yolk index (yolk index) using the following formula :

$$
\text { Egg Yolk Index }=\frac{a}{b}
$$


Information :

a : high egg yolk

$\mathrm{b}$ : diameter of egg yolk

\section{Haugh Unit}

Haugh unit is one of the determinants of egg quality. Haugh unit is a unit used to determine the freshness of the contents of the egg, especially the egg whites. Card and Nesheim (1972) put forward the Haugh Unit formula made by Raymound Haugh in 1937. For Haugh Unit calculations using the formula:

HU: 100 logs $\left(H+7.57-1.7 . W^{0.37}\right)$

Information :

$\mathrm{H}$ : High White Thick Egg (mm)

W: Egg Weight (gram / item)

\section{Results and Discussions}

\section{Treatment Rate}

The ration consisting of several animal feed raw materials, combined as in the treatment and arranged based on the calculations in Table 1 with different percentages for each treatment. The rations are processed in such a way as to fulfill nutritional needs of layer laying ducks (age> 20 weeks) according to Sinurat (2000) that laying ducks over 20 weeks old need rations with nutrient content in the form of Energy Metabolism (EM) of $\pm 2700 \mathrm{kcal} / \mathrm{kg}$, crude protein (PK) around 17-19\%, calcium (Ca) is $2.9-3.25 \%$, and phosphorus (P) is $0.6 \%$ as in Table 7 , while paying attention to the limits of the use of raw materials to avoid influencing the content of antinutrients contained in feed for digestive health of livestock if their use is excessive.

Table 1. The composition of the diet and the content of the dietary nutrition diet

\begin{tabular}{llllll}
\hline \hline \multirow{2}{*}{ No. } & \multirow{2}{*}{ Feed ingredients } & \multicolumn{4}{l}{ Treatment (\% ration) } \\
& & P0 & P1 & P2 & P3 \\
\hline 1. & Rice Bran & 70 & 58.8 & 53.9 & 49 \\
2. & Yellow Corn & 30 & 25.2 & 23,1 & 21 \\
3. & Golden Snail Powder & 0 & 6 & 8 & 10 \\
4. & Fermented Coconut Cake & 0 & 10 & 15 & 20 \\
\hline \multirow{2}{*}{ Total } & & 100 & 100 & 100 & \multirow{2}{*}{100} \\
\hline
\end{tabular}

Table 2. Nutrient content of raw materials for treatment rations (\% BK)

\begin{tabular}{llllrl}
\hline \multirow{2}{*}{ No. } & Nutrient content & \multicolumn{5}{c}{ Treatment } \\
& & PO & P1 & P2 & P3 \\
\hline 1. & ME (kcal / Kg) & 2670 & 2605.3 & 2580.45 & 2555,6 \\
2. & PK (\%) & 10.95 & 15,71 & 17,7375 & 19,765 \\
3. & Ca (\%) & 0.146 & 0.31344 & 0.36882 & 0.4242 \\
4. & $\mathrm{P} \mathrm{( \% )}$ & 7,643 & 7,664 & 7,671 & 7,678 \\
\hline \hline
\end{tabular}

The results of the combination feed in the form of pasta or semi-solid rations are easily consumed by ducks. The total feed given to livestock is $160 \mathrm{~g} /$ duck/day. This is based on Wakhid 
(2013) feeding for adult laying ducks after the age of 5 months can be as much as 100 grams of flour in the form of feed and feed in the form of granules as much as 60 grams. The total feed given is around 160 grams per head per day. All of this duck looks healthy and consume treated rations well during the study.
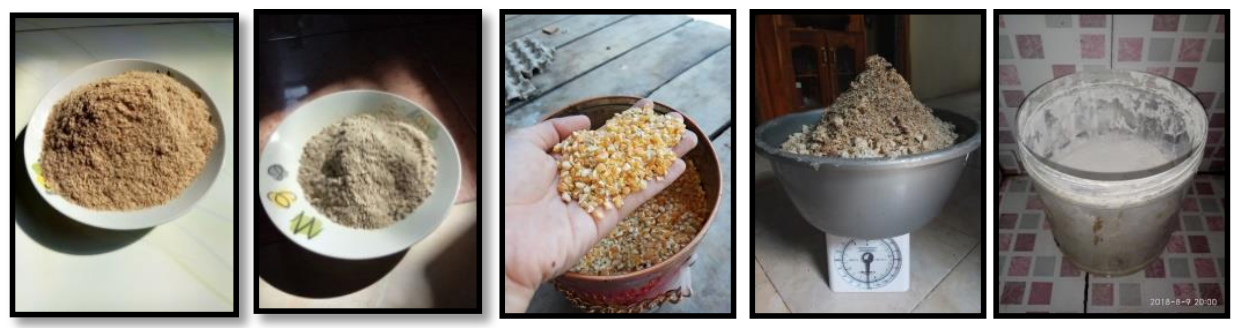

Figure 1 . Basic Treatment Ration (Personal Documentation)

The results obtained during the study took place as follows:

\section{Egg Weight}

The mean egg weight during the study of each treatment is presented in Table 3 .

Table 3 . Average Egg Weight During Research (g)

\begin{tabular}{lllllll}
\hline & \multirow{2}{*}{ Treatment } & \multicolumn{6}{c}{ Deuteronomy } & \multirow{2}{*}{ Average } \\
\cline { 2 - 5 } & & \multicolumn{6}{c}{2} & \multicolumn{1}{c}{3} & \multicolumn{1}{c}{4} & \\
\hline P0 & 48 & 47.2 & 52 & 48.2 & 48.85 \\
P1 & 48.9 & 49.6 & 50.7 & 57.4 & 51.65 \\
P2 & 49.5 & 54,9 & 47 & 56 & 51.85 \\
P3 & 48.6 & 54.3 & 51.8 & 53.9 & 52.15 \\
\hline \hline
\end{tabular}

From the results of Table 3 . The average egg weight during the study ranged from 48,85 $52.15 \mathrm{~g}$. The results obtained during this study indicate that the eggs produced are small. Agree with Puspitasari (2010) the average egg weight of Tegal duck is 65-70 g / grain, Alabio duck 65-70 g / grain, Bali duck $49 \mathrm{~g} /$ grain and Mojosari duck $65 \mathrm{~g}$. Huang and Lin (2011) added that because of the large number of varieties in laying duck species spread throughout the world, the weight range of duck eggs is 60-90 g. Percentage of eggshell, egg white and egg yolk from all eggs, each accounted for $11-13 \%, 45-58 \%$, and $28-35 \%$ respectively. The results of the variance of the weight of the eggs showed a not significant difference $(P>0,05)$. This means that the addition of a SKM combination of up to $10 \%$ and BKT up to $20 \%$ does not affect egg weight.

Different variance results are not significant due to the period or period of laying eggs of ducks which are still classified as the initial production phase (the first 6 months) which produce smaller eggs compared to the parent classified as productive phase or often lay eggs. This is in accordance with the opinion of Suharno (2010), the mother who spawn for the first time will produce eggs that look large but contain more water and smaller egg yolks and thin shells. Eggshell

In this study the factors considered by researchers were the effect of protein, calcium and phosphorus in the ration on external quality. According to North and Bell's (1990) opinion, external quality focuses on skin cleanliness, texture, shape, skin color, skin surface texture, and egg integrity. The results of each treatment on the external quality of eggs are presented in Table 4. 
Table 4. External Quality of Each Egg Treatment

\begin{tabular}{|c|c|c|c|c|c|}
\hline \multirow{2}{*}{ No. } & \multirow{2}{*}{ Quality factor } & \multicolumn{4}{|c|}{ Treatment } \\
\hline & & PO & P1 & P2 & P3 \\
\hline \multirow[t]{5}{*}{1.} & Shell condition & & & & \\
\hline & A. Shape & Normal & Normal & Normal & Normal \\
\hline & B. Fineness & Smooth & Smooth & Smooth & Smooth \\
\hline & C. Integrity & Intact & Intact & Intact & Intact \\
\hline & D. Cleanliness & $\begin{array}{l}\text { There is a little } \\
\text { dirty stain }\end{array}$ & $\begin{array}{l}\text { There is } \\
\text { stain }\end{array}$ & Clean & Clean \\
\hline \multirow[t]{3}{*}{2.} & Air Bag Condition & hrough Candling & & & \\
\hline & $\begin{array}{l}\text { A. Depth of Air } \\
\text { Bag }(\mathrm{mm})\end{array}$ & 6 & 5 & 7 & 5 \\
\hline & $\begin{array}{l}\text { B. Freedom of } \\
\text { movement }\end{array}$ & Free to move & $\begin{array}{l}\text { Free to } \\
\text { move }\end{array}$ & $\begin{array}{l}\text { Free to } \\
\text { move }\end{array}$ & $\begin{array}{l}\text { Free to } \\
\text { move }\end{array}$ \\
\hline
\end{tabular}

Based on Table 4., eggs produced from treatments $\mathrm{PO}$ and $\mathrm{P} 1$ belong to grade $\mathrm{B}$ and eggs produced from treatments P2 and P3 are classified as AA grade. In accordance with Suharno (1996) regarding the level of physical quality of duck eggs based on the condition of the shells that duck eggs that have a normal shape, the surface of the shell is clean and does not break into AA grade, for duck eggs that are clean, not broken, there is a slight crack and shape normal classified as grade A, and for duck eggs with shells that are not broken, not cracked, and there is little dirt on the shell (about 1/32 - 1/16 part of the eggshell surface) is classified as grade B, sertagrade $C$ has assessment criteria in the form of a broken, cracked shell, and a small amount of dirt on the shell (about 1/32 - 1/16 part of the eggshell surface) and normal shape.

In addition to the assessment factors based on the cleanliness of the skin, texture, shape, and texture of the surface of the eggshell, other factors that affect the quality of duck eggs are assessed from the condition of the color of the duck eggs. From each egg produced from the treatment, the eggshell color is bluish green which indicates that almost all eggs produced are of good quality. According to Huang and Lin (2011) eggshell quality is better observed in blue egg duck eggs compared to white shell skin. The cuticle on the blue duck eggshell is good and firm compared to the interstitial structure that is spread on white duck eggshells. Palisade blue shells are more compact than white shells. Blue egg shells contain biliverdin and protoporphyrin, while only protoporphyrin is observed in white eggshells. These factors are thought to provide some influence on the quality of egg shells that are better in ducks compared to chickens.

The quality of eggs is also affected by the presence of egg pockets in the blunt part of the egg. The longer the storage the larger the size of the egg bag, because evaporation of water will cause attachment of the outer membrane to the shell, and the inner membrane attaches to albumin (Gary et al, 2009 ).

Classification of the physical quality of duck eggs based on air bag conditions according to Suharno (1996) namely duck eggs with air bag depth $<3 \mathrm{~mm}$ and movement of about $6 \mathrm{~mm}$ classified as AA grade, duck eggs with air bag depths between $2-6 \mathrm{~mm}$; movement of about 6 $\mathrm{mm}$; and the edge of the yolk circle is still classified as grade $A$. Whereas for grade $B$ the depth of the air bag is between $7-8 \mathrm{~mm}$; irregular but not bubbling movements and for grade $C$ air bag depth> $9 \mathrm{~mm}$; unlimited movement; the edge of the circle of air bags is irregular and has ballooned.

Eggs produced from each treatment are eggs produced from treatments P0, P1, and P3 classified as grades with depth of air bag within $6 \mathrm{~mm}$ and freedom of movement of yellow and egg white when telescoped are clearly free to move. While eggs are produced from treatment P2 
is classified as grade B with an air bag depth of $7 \mathrm{~mm}$ and freedom of movement of the egg when telescoped looks free to move. Shellfish quality is influenced by nutrient content of rations, livestock health, maintenance management and environmental conditions. Eggshell contains about $95 \%$ calcium in the form of calcium carbonate and the rest is magnesium, phosphorus, sodium, potassium, zinc, iron, manganese, and copper (Gary et al., 2009).

\section{Egg White Index}

The mean egg white index during the study of each treatment is presented in Table 5 .

Table 5 . Average Egg White Index During Research

\begin{tabular}{llllll}
\hline \hline \multirow{2}{*}{ Treatment } & \multicolumn{4}{l}{ Deuteronomy } & Average \\
\cline { 2 - 5 } & 1 & 2 & 3 & 4 & 0.0675 \\
\hline P0 & 0.08 & 0.07 & 0.07 & 0.05 & 0.06 \\
P1 & 0.07 & 0.05 & 0.06 & 0.06 & 0.0675 \\
P2 & 0.07 & 0.05 & 0.09 & 0.06 & 0.0725 \\
P3 & 0.08 & 0.06 & 0.07 & 0.08 & \\
\hline \hline
\end{tabular}

From the results of Table 5. The average egg white index of each treatment ranged from 0,06 $-0,0725$ These results indicate that the egg white index is included in good quality. According to Abraham and Ravindran (2009) duck eggs have an albumin index ranging from 0.056 to 0.072. According to Huang and Lin (2011) the index of egg white during storage at $2-44^{\circ} \mathrm{C}$ has an albumin index of around $0.061-0.079$. eggs at a temperature of $2^{\circ} \mathrm{C}-37^{\circ} \mathrm{C}$ with a storage time of 7 - 37 days having an index ranging from $0.09-0.10$. A better egg white index than other treatments was obtained from ducks given a combination ration of $10 \%$ SKM and $20 \%$ BKT.

The results of the analysis of the egg white index variance showed no significant difference $(P>$ 0,05 ). This shows that a combination of TKM and BKM can be used to $10 \%$ and $20 \%$ respectively in the ration without affecting the egg white index. In a study conducted by Purnamaningsih (2010) that the weight of eggs produced was not significantly different, so the index of egg white produced also showed different results that were not real. This is supported by the statement of Nesheim et al. (1979), the quality of the inside of an egg is influenced by body size and the size and weight of eggs.

\section{Egg Yolk Index}

The mean egg yolk index during the study of each treatment is presented in Table 6 .

Table 6. Average Egg Yolk Index During Research

\begin{tabular}{llllll}
\hline \multirow{2}{*}{ Treatment } & \multicolumn{2}{l}{ Deuteronomy } & \multirow{2}{*}{ Average } \\
\cline { 2 - 5 } & 1 & 2 & 3 & 4 & \\
\hline P0 & 0.36 & 0.40 & 0.38 & 0.38 & 0.38 \\
P1 & 0.42 & 0.32 & 0.35 & 0.36 & 0.3625 \\
P2 & 0.34 & 0.36 & 0.42 & 0.39 & 0.3775 \\
P3 & 0.49 & 0.41 & 0.43 & 0.46 & 0.4475 \\
\hline \hline
\end{tabular}

From the results of Table 6 . The average yolk index of each treatment ranged from 0,36-0.45. These results indicate that the egg yolk index is included in good quality. According to Abraham 
and Ravindran (2009) those eggs have an index of egg yolk ranging from $0,31-0,70$, Whereas according to Huang and Lin (2011) the index of the yolk during storage at a temperature of 2 $44^{\circ} \mathrm{C}$ has a yellow index of about 0,38 - 0.45. Pikul (1998) added that the index of the yolk during storage at $2-37^{\circ} \mathrm{C}$ has a yellow index of about $0,34-0,41$. Of the four treatments the best IKT was shown by treatment P3 with an IKT average of 0,45. Australiananingrum (2005) states that the higher the protein and fat content in the ration, the higher the yolk index. From the results obtained it can be said that the amount of protein contained in the P3 ration is optimal enough to produce eggs with a good egg yolk index.

\section{Egg Yolk Color}

The average yolk color during the study of each treatment was measured using the color metering tool that produced the values $L * a * d a n b *$ and presented in Table 7 . The value of $L *$ indicates the brightness of the color, $a *(+)$; red, $b *(+)$; yellow, the higher the $L *$ value indicates the yolk is getting brighter, the higher the value of $b *(+)$ the color of the yolk is getting yellow, the higher the value of a * $(+)$ the color of the yolk is getting red (Putra et al., 2012).

The color $L *, a *, b *$ is a color space that gives the views and meanings of each dimension that is formed, namely the amount of $L$ * to describe the brightness of colors (values 0 to 100). Where the value 0 indicates black and the value 100 indicates white. Color a * describes the type of green-red (values -120 to +120 ). Color $b *$ for blue-yellow types (values -120 to +120 ). The color models $L *, a *, b *$ are often used in food research studies (Yam and Papadakis, 2004). Delta or difference for $\mathrm{L} *(\mathrm{~L} *=\mathrm{L} *$ sample minus $\mathrm{L} *$ control $), a *(a *=a *$ sample minus $a *$ control $), b *(b *=b *$ sample minus $b *$ control $)$ can be worth positive $(+)$ or negative (-). The total color difference or Delta $E(E *)$ is always positive. To determine the total color difference between the three coordinates in Table 8 ,

a formula is used $\Delta E_{a b}=\sqrt{\left(\Delta L^{*}\right)^{2}+\left(\Delta a^{*}\right)^{2}+\left(\Delta b^{*}\right)^{2}}$ (Hadianti and Riana, 2018).

Table 7. Average of Egg Yolk Color

\begin{tabular}{lllllll}
\hline \hline \multirow{2}{*}{ Treatment } & \multicolumn{5}{c}{ Color } & \multicolumn{5}{c}{ Average } \\
\cline { 2 - 7 } & $\mathrm{L} *$ & $\mathrm{a} *$ & $\mathrm{~b} *$ & $\mathrm{~L} *$ & $\mathrm{a} *$ & $\mathrm{~b} *$ \\
\hline \hline & 66.81 & 11,4867 & 45,7333 & & & \\
P0 & 65,5733 & 16.11 & 38.67 & 68,357 & 12 & 40,441 \\
& 67,9667 & 11,115 & 32,9067 & & & \\
& 73.0767 & 9.83 & 44,4533 & & & \\
P1 & 62.61 & 7,335 & 42,5433 & & & 41,079 \\
& 65,3833 & 9.52167 & 34,2867 & 64,671 & 9 & \\
& 63.01 & 9.59833 & 44.74 & & & \\
P2 & 67,68 & 10.9733 & 42,7467 & & & \\
& 66,6667 & 11.97 & 47.42 & & & \\
& 64,1067 & 8,40833 & 47.05 & 64,611 & 12 & \\
& 61,5933 & 10,245 & 47.9 & & & \\
P3 & 66.0767 & 17,9633 & 28,84 & & & \\
& 63,2467 & 8.99 & 49,5433 & & & \\
& 63,3633 & 8,545 & 44.0467 & 63,577 & 10 & \\
\hline \hline
\end{tabular}

Description: L * (Brightness); a * (Redness); b * ( Yellowish) 
Table 8 . Total Color Difference

\begin{tabular}{|c|c|c|c|c|}
\hline Color & Control Average & Treatment Sample & $\begin{array}{l}\text { L Color } \\
\text { Difference * a * b } \\
*\end{array}$ & $\Delta \mathrm{E} *$ \\
\hline$L *$ & 68,357 & 64,671 & $\Delta \mathrm{L} *:-3,686$ & \multirow{3}{*}{4,795} \\
\hline$a *$ & 12 & 9 & $\Delta \mathrm{a} *:-3$ & \\
\hline$b *$ & 40,441 & 41,079 & $\Delta \mathrm{b} *:+0,638$ & \\
\hline$L^{*}$ & 68,357 & 64,611 & $\Delta \mathrm{L} *:-3,746$ & \multirow{4}{*}{4,428} \\
\hline$a *$ & 12 & 12 & $\Delta a *: 0$ & \\
\hline & & & & \\
\hline$b$ * & 40,441 & 42,8025 & $\Delta \mathrm{b} *:+2,361$ & \\
\hline Color & Control Average & Treatment Sample & $\begin{array}{l}\text { LColor } \\
\text { Difference * a * b } \\
*\end{array}$ & $\Delta \mathrm{E} *$ \\
\hline$L *$ & 68,357 & 63,577 & $\Delta \mathrm{L} *:-4.78$ & \multirow{3}{*}{5,803} \\
\hline$a *$ & 12 & 10 & $\Delta a *:-2$ & \\
\hline$b *$ & 40,441 & 43,053 & $\Delta \mathrm{b} *:+2,612$ & \\
\hline
\end{tabular}

Description: $\Delta \mathrm{L} *=$ Total brightness; $\Delta \mathrm{a} *=$ Total redness; $\Delta \mathrm{b} *=$ Total yellowness $\Delta \mathrm{E} *=$ Total color difference

The results showed that the yolk color between control and treatment had differences, P1 egg yolk was less bright, less red, and more yellow than PO egg yolk with a total difference of 4,795. Whereas for egg yolk P2 is less bright, the red color was same, and more yellow than the egg yolk PO with a total difference of 4,428 . For P3 egg yolks are less bright, less red, but more yellow than egg yolks PO. Of the three samples compared with control egg yolks, which had more difference in egg yolk with treatment P3 with a total difference of 5,803 where the color of the yolk produced was dependent on the carotenoid pigments contained in the rations consumed by livestock during the study. Yellow corn and golden snail are feed ingredients that contain xantophyl substances so that it easily affects the color of the yolk. The results obtained from each treatment showed a treatment effect on the density of the yolk color. Information on the value of $L *, a *, b$ * in egg yolk can be seen in Figure 2.

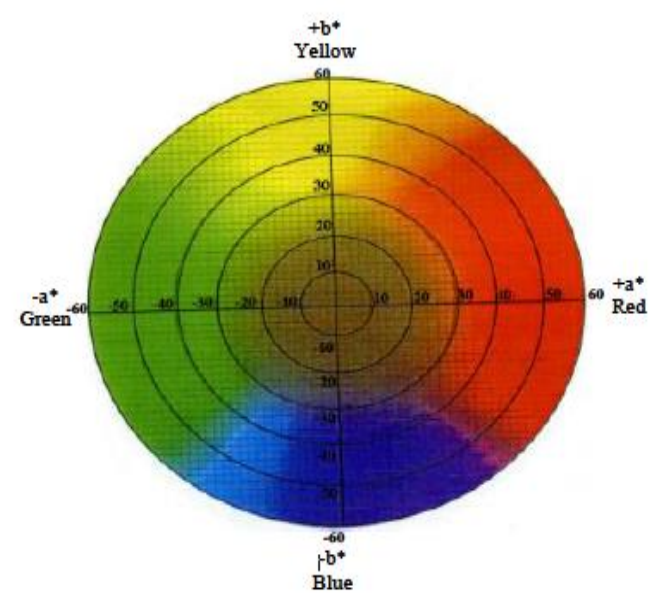

Figure 2 : Reference to $L *, a *, b *$ values for color analysis (Putra et al., 2012) 
Haugh Unit Value (HU)

The mean haughty value of egg units during the study of each treatment is presented in Table 9 .

Table 9 . Average Haugh Value of Egg Units During Research

\begin{tabular}{llllll}
\hline \multirow{2}{*}{ Treatment } & \multicolumn{2}{l}{ Deuteronomy } & \\
\cline { 2 - 5 } & 1 & 2 & 3 & 4 & \\
\hline P0 & 72.4 & 71.3 & 70.8 & 70.9 & 71.35 \\
P1 & 71,9 & 70.6 & 70.2 & 69.9 & 70.65 \\
P2 & 72.5 & 70.2 & 72.5 & 70.6 & 71.45 \\
P3 & 72,1 & 69.9 & 71.8 & 70,1 & 70,975 \\
\hline \hline
\end{tabular}

From the results of Table 9. The mean value of $\mathrm{HU}$ from each treatment ranged from 70.65 71.45. The results of the analysis of variance showed no significant difference $(P>0,05)$ to the value of HU. This shows that the combination of SKM and BKM has no effect on the value of HU. According to Stadellman and Cotteril (1995) duck eggs that have just been spawned have $\mathrm{HU}$ values of 100, eggs of good quality have HU 75 values, and eggs that are damaged value $\mathrm{HU}$ below 50. Nesheim et al. (1979) argued that there was a positive correlation between egg whites and $\mathrm{HU}$ values, namely the higher the egg white, the higher the value of $\mathrm{HU}$ produced. Suharno (1996), added that HU duck eggs with AA quality have the criteria that the egg whites look clear, colorless, still static, if $\mathrm{HU}$ measurements have a 72 index, quality $\mathrm{A}$ with egg whites looks clear, but less static and has an index between $60-70$, quality $B$ with the criteria for egg whites looks clear, rather liquid and not static and $\mathrm{HU}$ index between 31 - 60, and quality $\mathrm{C}$ has $\mathrm{HU}$ index below 31. The high value of $\mathrm{HU}$ is affected by how thick the egg white is produced. The results showed that the eggs produced from the four treatments were classified as A.

\section{Conclusion}

All treatments (P1, P2, P3) gave effect to three parameters, namely eggshell quality, egg yolk index and egg yolk color, while the other three parameters namely egg weight, egg white index and haugh unit value did not differ significantly from negative controls. The best treatment was shown by treatment P3 which gave an effect on the heavier egg weight than other treatments, eggshell quality grade A, Egg White Index and Egg Yolk Index showed good quality and bright golden egg yolks.

\section{Refferences}

John, A and Ravindran, R. (2009). Studies on the Aroor system of sustainable duck rearing in Kerala, India. Int. J. Poult. Sci, 8, 804-807.

Hadianti, SRI and Riana, Dwiza (2018). Sistem Pengenalan Otomatis Diameter Citra Mantoux Untuk Deteksi Dini Penyakit Tbc Kelenjar. Jurnal Techno Nusa Mandiri, 15(2), 77-84.

Huang, JF, and Lin, CC. (2011). Production, composition, and quality of duck eggs. In Improving the Safety and Quality of Eggs and Egg Products: Egg Chemistry, Production and Consumption (pp. 487-508). 
Indrawan, IG, Sukada, IM and Suada, IK. 2012. Kualitas telur dan pengetahuan masyarakat tentang penanganan telur di tingkat rumah tangga. Indonesia Medicus Veterinus, 1(5), pp.607-620.

Putra, GH, Nurali, EJ, Koapaha, T and Lalujan, LE. 2013. Pembuatan Beras Analog Berbasis Tepung Pisang Goroho (Musa Acuminate) Dengan Bahan Pengikat Carboxymethyl Celluloce (CMC). In COCOS (Vol. 2, No. 4).

Sinurat, AP, Purwadaria, T, Habibie, A, Pasaribu, T, Hamid, H, Rosida, J, Haryati, T dan Sutikno, I. 1998 . Nutritive Value Of Fermented Coconut Meal In Ration Of Laying Ducks With Various Phosphorous Levels.Jurnal IImu Ternak Dan Veteriner 3 (1): 15-21.

TES Electrical Electric Corp. 2014. Light Meter [Online]. Diakses pada tanggal 16 Mei 2018 http://www.tes.com.tw/en/product_detail.asp?seq $=364$

Yam KL dan Papadakis SE. 2004. A Simple Digital Imaging Method for Measuring and Analyzing Color of Food Surfaces. Jurnal of Food Engineering. 61: 137-142.

Yessirita N, Abbas, MH, Heryandi, Y, dan Dharma, A. 2015. Peningkatan Kualitas Telur Itik Pitalah dengan Pemberian Pakan Serbuk Daun Lamtoro (Leucaena leucochepala) yang Difermentasi dengan Bacillus laterosporus dan Trichoderma viride. Universitas Andalas. Jurnal Peternakan Indonesia, Februari 2015 Vol. 17 (1) ISSN 1907-1760

Yunidawati, W, Bakti, D and Damanik, BSJ. 2011. Penggunaan Ekstrak Biji Pinang untuk Mengendalikan Hama Keong Mas (Pomacea canaliculata Lamarck) pada Tanaman Padi. Jurnal Ilmu Pertanian Kultivar, 5(2). 